\title{
Cux/ZnO-y Catalysts. Effect of Support Modification by High Energy Milling on the Metal-Support Interaction ${ }^{+}$
}

\author{
Maria K. López González*, Luis E. Cadús and Maria R. Morales \\ Instituto de Investigaciones en Tecnología Química (INTEQUI-CONICET), Universidad Nacional de San Luis \\ (UNSL), Facultad de Química, Bioquímica y Farmacia, Almirante Brown 1455, Capital, 5700 San Luis, \\ Argentina; luiscadus@gmail.com (L.E.C.); mrmorale14@gmail.com (M.R.M.) \\ * Correspondence:orrespondence: mklopezglez@gmail.com (M.K.L.G.) \\ + Presented at the 1st International Electronic Conference on Catalysis Sciences, 10-30 November 2020; \\ Available online: https://sciforum.net/conference/ECCS2020.
}

Published: 10 November 2020

\begin{abstract}
Commercial $\mathrm{ZnO}$, was subjected to high-energy milling to introduce structural modifications, which can result in a different metal-support interaction. The milling time (0 to 960 min) and vial material and mill balls ( $\mathrm{WC}$ and $\mathrm{ZnO}_{2}$ ), were modified. The supports were characterized by XRD, Scherrer, $\mathrm{S}_{\mathrm{BET}}$ and Raman Spectroscopy. With the increase in milling time, an increase in the accrued kinetic energy (Ecum) was observed. For the same Ecum, with $\mathrm{ZrO}_{2}$, twice the area was obtained in just $6 \mathrm{~min}$. Cu was deposited on both, the milled support ( $\mathrm{ZnO}-\mathrm{z}$ ) and unmilled support $(\mathrm{ZnO}-0)$ in three compositions; $\mathrm{x}=0.2,0.5$, and $1.0(\% \mathrm{wt})$. AAS measurements showed $\mathrm{Cu}$ compositions similar to the theoretical ones. XRD studies, Rietveld modelling and Raman Spectroscopy confirmed that $\mathrm{Cu}^{2+}$ cations could be localized, either by substituting the $\mathrm{Zn}^{2+}$ ions or interstitially in the network, depending on the metal content. The TPR profiles showed two types of copper species, which interact differently with the support. Likewise, the analysis of the XPS results showed that, with the increase in $\mathrm{Cu}$ content, for $\mathrm{Cux} / \mathrm{ZnO}-0$, there is a decrease in the metal-support interaction. However, for Cux/ZnO-z the interaction increases, which can be associated with the introduction of structural defects accompanied by superficial energy changes. For both systems, different catalytic behaviours are expected in the hydrogenolysis reaction of glycerol in liquid phase, regarding selectivity and stability, as a result of the metal-support interaction achieved.
\end{abstract}

Keywords: zinc oxide; copper; high energy milling; metal-support interactions

\section{Introduction}

The selectivity towards one or more reaction products exclusively depends on the structural characteristics and the physical-chemical surface of the catalyst used. In the glycerol hydrogenolysis reaction, the supports have a strong involvement in the selectivity towards a determined reaction product. In particular, the metal-support interaction plays a key role, although it has been less investigated. The specific surface area, the superficial structural defects such as oxygen vacancies, and the acidity-basicity are, among others, characteristics that define the use or not of a metal oxide as support. These characteristics, together with the method of deposition of the metallic precursor, define the size of metallic domains, their dispersion, and the type of interaction that can occur between them.

High energy milling is considered a novel method in the synthesis of materials. This method allows us to achieve transformations of crystalline phases, an increase in surface areas and it has even been used in the activation of precursors of different catalytic systems. Moreover, it is a very powerful technique for the synthesis of catalytic materials due to the extreme conditions of pressure and 
temperature that are locally reached [1]. The $\mathrm{Cu}-\mathrm{ZnO}$ catalytic system has been successfully used in the hydrogenolysis reaction of glycerol, which has been mainly associated with the dispersion of $\mathrm{Cu}$ with small particle sizes [2]. However, very few studies have revealed that the interfacial area between $\mathrm{Cu}$ and $\mathrm{ZnO}$ plays a crucial role in the activity and the stability of the $\mathrm{Cu}-\mathrm{ZnO}$ system [3]. Unfortunately, the role of the interface between $\mathrm{Cu}$ and $\mathrm{ZnO}$ in the hydrogenolysis of glycerol has been rarely reported.

The objective of this work is to modify the $\mathrm{ZnO}$ structural and surface characteristics due to a high energy milling, and then, to use it as catalytic support. The aim is to study the $\mathrm{Cu}-\mathrm{ZnO}$ interaction achieved when the support is milled and compare it with the same system using the unmilled support.

\section{Materials and Methods}

\subsection{Support and Catalysts Preparation}

Commercial $\mathrm{ZnO}$ was subjected to high energy milling in a planetary ball mill (Fritsch Pulverisette 6). Four balls $(1.5 \mathrm{~cm} \varnothing)$ and a vial $(7.0 \mathrm{~cm} \varnothing)$ of $W C$ and 2466 balls $(0.5 \mathrm{~cm} \varnothing)$ and a vial $(10.0 \mathrm{~cm} \varnothing)$ of $\mathrm{ZrO}_{2}$ were used. For WC, a mass of balls: mass of powder ratio (BPR) of 35:1, rotation speed of $300 \mathrm{rpm}$ and milling times of 0, 5, 30, 60, 240, 480 and 960 min were used. While with $\mathrm{ZrO}_{2}$ a BPR of 148:1 and $300 \mathrm{rpm}$ were used and it was milled for $6 \mathrm{~min}$. This support was named ZnO-z. Copper acetate was deposited by impregnation at incipient moisture on unmilled zinc oxide (ZnO$0)$ and milled $(\mathrm{ZnO}-\mathrm{z})$. Three compositions of $\mathrm{Cu}(\% \mathrm{wt})$ were used. The catalytic systems were named: Cux/ZnO-0 and Cux/ZnO-z, with $\mathrm{x}=0.2,0.5$ and 1.0.

\subsection{Characterization}

Supports and catalysts were characterized by means of X-ray Diffraction (XRD), BrunauerEmmet-Teller (BET) method, Raman spectroscopy, Atomic Absorption Spectroscopy (AAS), X-ray Photoelectron Spectroscopy (XPS) and Temperature Programmed Reduction (TPR).

\section{Results and Discussion}

Commercial $\mathrm{ZnO}$ with a low surface area was subjected to milling. When WC was used, an increase in accumulated kinetic energy (Eacum) was observed with increasing the milling time [1].

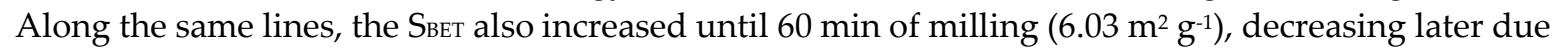
to a process of agglomeration of the particles. To determine the effect of the use of $\mathrm{ZrO}_{2}$ on the support, the Eacum of the WC at $60 \mathrm{~min}$ of milling was taken as a reference, and the time necessary to reach it was calculated, which was only $6 \mathrm{~min}$. Milled $\mathrm{ZnO}$ presented a SвET three times higher than that of the unmilled support (Table 1); Therefore, it was selected as a support for the Cux/ZnO-z system. In order to determine the effect of milling on the metal-support interaction, the Cux/ZnO-0 system was synthesized as a reference. The characterization of the supports is not presented due to the space limit.

XRD diffractograms are shown in Figure 1. In both systems, diffraction lines typical of the hexagonal system of wurtzite (PDF 96-90-4181) can be observed, without any diffraction lines corresponding to phases containing $\mathrm{Cu}$. This may be due to its low $\mathrm{Cu}$ concentration, high dispersion and/or the incorporation of $\mathrm{Cu}$ ions in the $\mathrm{ZnO}$ structure. The observed shift of the most intense diffraction signal (101) of $\mathrm{ZnO}$ (Figure 1) indicates the incorporation of $\mathrm{Cu}$ into the $\mathrm{ZnO}$ lattice, in different extensions, in both systems. In the $\mathrm{Cux} / \mathrm{ZnO}-0$ system, the increase of the $\mathrm{Cu}$ content leads to a decrease in the displacement. $\mathrm{Cu} 0.2 / \mathrm{ZnO}-0$ shows the highest displacement, which is a sign of constant lattice contraction. This can be attributed to the internal relaxation of the lattice, due to the incorporation of $\mathrm{Cu}^{2+}$ ions $(0.073 \mathrm{~nm})$ in the bigger $\mathrm{Zn}$ sites $(0.074 \mathrm{~nm})$ [4]. For $0.5 \%$ and $1.0 \%$, the lower displacements can be associated with a lower incorporation of $\mathrm{Cu}^{2+}$ in the $\mathrm{ZnO}$ lattice, and a favouring of the nucleation process and the subsequent growth rate of $\mathrm{CuO}$, due to the higher concentration of $\mathrm{Cu}$. Contrary to $\mathrm{Cux} / \mathrm{ZnO}-\mathrm{z}$, the diffraction lines shift towards greater angles with increasing $\mathrm{Cu}$ content. This can be associated with the continuous migration of the $\mathrm{Cu}^{2+}$ species in the 
$\mathrm{ZnO}$ matrix, occupying positions in its planar defects, whose content is higher in $\mathrm{ZnO}-\mathrm{z}$ due to milling.
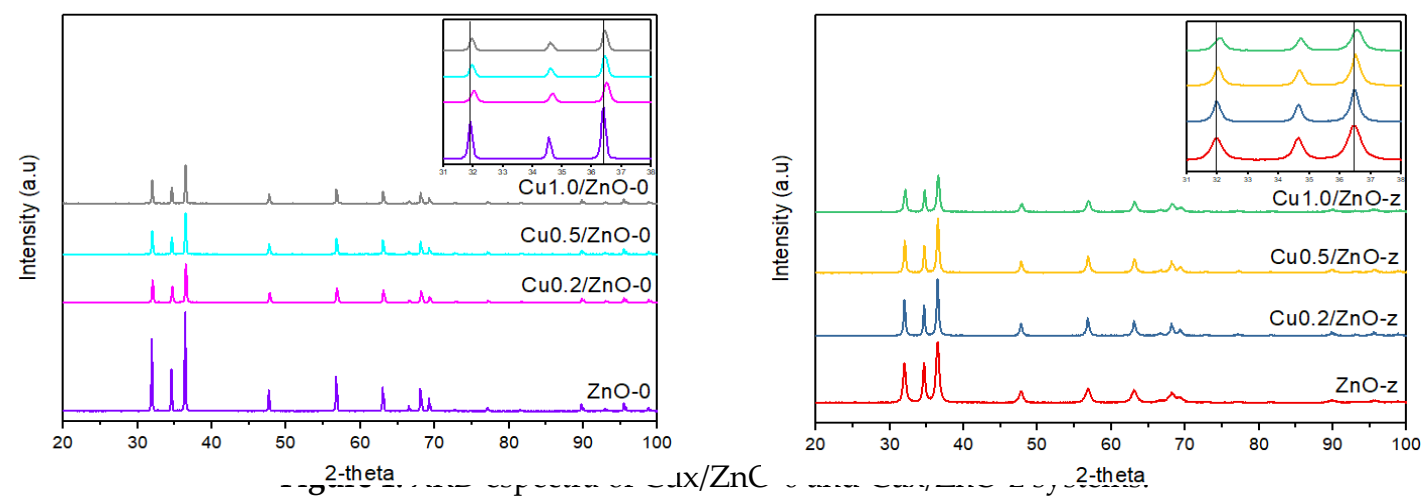

Different parameters of the $\mathrm{ZnO}$ crystal structure, for both systems, calculated from the XRD data, Scherrer equation and Rietveld modelling are presented in Table 1 [4]. For Cux/ZnO-0 it can be observed that the $\mathrm{D}$ values are lower than those with the support, which can be associated with the alteration in the host lattice, due to the insertion of $\mathrm{Cu}$. However, $\mathrm{D}$ increases with the increase in $\mathrm{Cu}$ content, indicating a lower insertion of $\mathrm{Cu}^{2+}$ in the $\mathrm{ZnO}$ lattice, in line with what was observed by $\mathrm{XRD}$. The $\mathrm{ZnO}-\mathrm{z}$ support has a $\mathrm{D}$ lower than $\mathrm{ZnO}-0$, as a consequence of the milling. In Cux/ZnO-z, an increase in $\mathrm{D}$ is observed when $\mathrm{Cu}$ is added, which would indicate the incorporation of $\mathrm{Cu}$ in the $\mathrm{ZnO}$. However, $\mathrm{D}$ decreases when more $\mathrm{Cu}$ is added. Although with the increase in copper, more $\mathrm{Cu}^{2+}$ ions are incorporated, it is possible that they are located in positions that stabilize the $\mathrm{ZnO}-\mathrm{z}$ lattice and/or part of the $\mathrm{Cu}^{2+}$ located in tetrahedral positions is reduced to $\mathrm{Cu}^{+}$, which has a lower ionic radius $(0.060 \mathrm{~nm})$ and leads to external relaxation of the closest $\mathrm{O}$ atoms, contracting the crystalline lattice. It has been reported that $\mathrm{Cu}^{+}$ions can come from the transformation of $\mathrm{Cu}^{2+}$ ions that capture an extra electron from a nearby atom or in complexes with oxygen vacancies [5].

For both systems, the c/a cell parameters relationship changes concerning the supports, which indicates a structural deformation of the material [4], confirming the incorporation of $\mathrm{Cu}$ in it. For $\mathrm{Cux} / \mathrm{ZnO}-0$ the c/a ratio decreases, while no variations are observed when the $\mathrm{Cu}$ doping increases, which can be explained by a limited insertion of the cation in the support lattice, for the three catalysts. In Cux/ZnO-z, the c/a ratio is higher than that of the support and it increases with the addition of $\mathrm{Cu}$, due to its continuous incorporation into the structure. The intrinsic stress $(\xi)$ and the density of the grain boundaries (dislocations $(\delta)$ ) also provide information on stresses and defects introduced in the support crystalline lattice by the incorporation of an ion and/or milling [4]. In Table 1 , it can be observed that for the $\mathrm{Cux} / \mathrm{ZnO}-0$ system, the $\xi$ and $\delta$ values increase in the support, which can be attributed to the changes in the microstructure, size, and shape of the particles, due to the $\mathrm{Cu}$ insertion. However, $\xi$ and $\delta$ decrease with the increase of $\mathrm{Cu}$, which would indicate that the nucleation process of the $\mathrm{Cu}$ excess is favoured, instead its incorporation into the structure. As expected for the support subjected to milling, $\xi$ and $\delta$ present high values due to the great stresses and defects introduced in the lattice. In the Cux/ZnO-z system, with the addition of $\mathrm{Cu}, \xi$ and $\delta$ tend to decrease, which would indicate that the $\mathrm{Cu}$ atoms could occupy positions in the lattice, stabilizing it and releasing the stress generated by the milling. However, with the increase in $\mathrm{Cu}$ content, both increase due to a greater incorporation of $\mathrm{Cu}$, without reaching the values obtained for $\mathrm{ZnO}-\mathrm{z}$. Therefore, it could be said that doping with $\mathrm{Cu}$, in general, improves the stability of the lattice.

Raman spectroscopy corroborates what it is mentioned above. In the supports, the E2(high) no polar mode predominates at $\sim 438 \mathrm{~cm}^{-1}$, which it is characteristic of the wurtzite hexagonal phase. The intensity of this mode dramatically decreases with the milling. Also, it expands and increases its asymmetry, indicating a further disarray of the lattice. The absence of vibrational modes corresponding to the $\mathrm{Cu}$ oxide phases demonstrates its incorporation into the $\mathrm{ZnO}$ lattice and/or a

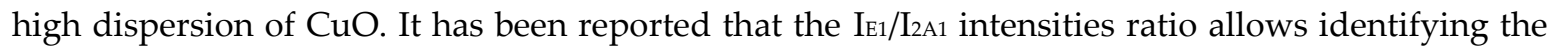
content of defects in a solid, in particular, the oxygen vacancy type [6]. For Cux/ZnO-0 this ratio is 
higher than for the support, but it decreases with the $\mathrm{Cu}$ content increase. However, for $\mathrm{Cux} / \mathrm{ZnO}-\mathrm{z}$ this ratio decreases considering the support, indicating a decrease in the number of defects and the $\mathrm{Cu}$ content increase.

Table 1. Data obtained from XRD, Scherrer equation, Rietveld modelling, AAS and Raman spectroscopy.

\begin{tabular}{|c|c|c|c|c|c|c|c|}
\hline Catalyst & $\mathrm{D}(\mathrm{nm})$ & $\mathrm{c} / \mathrm{a}$ & $\xi \times 10^{-4}$ & $\delta \times 10^{14}$ line $\mathrm{m}^{-2}$ & $S_{\text {вет }}\left(m^{2} g^{-1}\right)$ & $\mathrm{Cu}(\% w t)$ & $\mathrm{I}_{\mathrm{E} 1} / \mathbf{I}_{2 \mathrm{~A} 1}$ \\
\hline $\mathrm{ZnO}-0$ & 71.2 & 1.6026 & 15.60 & 1.97 & 3.8 & - & 0.18 \\
\hline $\mathrm{Cu} 0.2 / \mathrm{ZnO}-0$ & 44.0 & 1.6020 & 25.09 & 5.16 & 3.7 & 0.2 & 0.64 \\
\hline $\mathrm{Cu} 0.5 / \mathrm{ZnO}-0$ & 50.7 & 1.6020 & 22.00 & 3.89 & 3.5 & 0.56 & 0.31 \\
\hline $\mathrm{Cu} 1.0 / \mathrm{ZnO}-0$ & 55.8 & 1.6020 & 19.98 & 3.21 & 4.5 & 0.96 & 0.17 \\
\hline $\mathrm{ZnO}-\mathrm{z}$ & 16.8 & 1.6017 & 66.06 & 35.43 & 14.54 & - & 1.78 \\
\hline $\mathrm{Cu} 0.2 / \mathrm{ZnO}-\mathrm{z}$ & 31.7 & 1.6020 & 35.02 & 9.95 & 6.54 & 0.25 & 1.53 \\
\hline $\mathrm{Cu} 0.5 / \mathrm{ZnO}-\mathrm{z}$ & 28.6 & 1.6021 & 38.78 & 12.22 & 5.97 & 0.68 & 1.37 \\
\hline $\mathrm{Cu} 1.0 / \mathrm{ZnO}-\mathrm{z}$ & 21.1 & 1.6023 & 52.52 & 22.46 & 7.5 & 1.19 & 1.04 \\
\hline
\end{tabular}

The SвEт of the Cux/ZnO-0 system practically does not vary with the doping of $\mathrm{Cu}$. On the contrary, in the Cux/ZnO-z system, the SвEт decreases with the incorporation of $\mathrm{Cu}$, but increases with the increase of the $\mathrm{Cu}$ content. This could be associated with the impregnation stage, where the incorporated moisture and the subsequent calcination would favour the coalition of the $\mathrm{ZnO}$ small agglomerated particles, obtained during the milling. The impregnating solution of copper acetate with a $\mathrm{pH}=5.5-6.0$ could erode the $\mathrm{ZnO}$ surface, which is easily attacked by acids, explaining the slight increase in the $\mathrm{S}_{\text {BET }}$ with the increase in the $\mathrm{Cu}$ content, in both systems. The composition data, obtained by atomic absorption for both families, show excellent impregnation, since the experimental values are similar to the theoretical ones (Table 1 ).

XPS was used to understand the surface modifications introduced by the milling on the support, and the interaction achieved between the metal-support (Table 2). In both systems, shifts were observed in the $\mathrm{Zn} 2 \mathrm{p} 1 / 2$ and $2 \mathrm{p} 3 / 2$ signals, corresponding to $\mathrm{ZnO}[7]$ at higher binding energies (BE), with respect to the two supports; indicating a strong $\mathrm{Cu}-\mathrm{ZnO}$ interaction. In $\mathrm{Cux} / \mathrm{ZnO}-0$ the displacement decreases with increasing $\mathrm{Cu}$ content, which would indicate a decrease in this interaction as more $\mathrm{Cu}$ is deposited. An inverse behaviour can be observed in $\mathrm{Cux} / \mathrm{ZnO}-\mathrm{z}$, indicating a greater $\mathrm{Cu}-\mathrm{ZnO}$ interaction as more metal is deposited. $\mathrm{Cu} 2 \mathrm{p} 1 / 2$ and $2 \mathrm{p} 3 / 2$ signals also show shifts, but more marked for the two systems, but at lower $\mathrm{BE}$ than those reported in the literature for $\mathrm{CuO}$ (953.2 $\mathrm{eV}$ and $933.5 \mathrm{eV}$ ) [7]. This is associated with the $\mathrm{Cu}-\mathrm{ZnO}$ interaction. With increasing copper content, there is no linear behaviour. According to I. Kaskow et al. [7], the increase in the BE in Zn $2 \mathrm{p} 3 / 2$, and its decrease in the supported metal, implies an electronic transfer from the support to the metal. This could induce the reduction of $\mathrm{CuO}$ to $\mathrm{Cu}_{2} \mathrm{O}$, at the interface between the metal domain and the support, in both families. The presence of a satellite signal at $\sim 943 \mathrm{eV}$ is characteristic of materials having a $\mathrm{d} 9$ configuration in its highest oxidation state $(\mathrm{CuO})$. In $\mathrm{Cux} / \mathrm{ZnO}-0$, this satellite is almost imperceptible for $0.2 \%$, but its intensity increases with the $\mathrm{Cu}$ content. For Cux/ZnO-z, it can only be observed with a very low intensity $(1.0 \%)$. Although the $\mathrm{CuO}$ formation increases with the addition of $\mathrm{Cu}$, in both systems, its content is higher in the Cux/ZnO-0 system. The O1s signal was deconvolved into two signals (Table 2). These signals correspond to oxygen of the crystalline lattice, Olat, at 530.1-530.4 eV, and oxygen adsorbed in oxygen vacancies, Oads, at 531.7-532.3 eV. Milling causes a shift of these signals to lower BE, which is associated with internal stresses in the lattice, and generated defects. For $\mathrm{Cux} / \mathrm{ZnO}-0$, the Olat do not vary with the $\mathrm{Cu}$ content increase, but their signal moves to higher BE. This could be explained by the limited incorporation of the $\mathrm{Cu}$ in the $\mathrm{ZnO}$ lattice. On the contrary to Oads, its BE increases with the copper content, being higher than that of the support, which could indicate a strong interaction of $\mathrm{Cu}$ with these defects. Indeed, this is the case, since the total content of $\mathrm{O}_{\text {ads }}$ decreases with the addition of $\mathrm{Cu}$, which would indicate a selective 
adsorption of the metal in this type of defects, in line with the variations in the ratio of intensities observed by Raman. In Cux/ZnO-z, the Olat moves to higher BE and increases with the addition of copper. This can be associated with the constant incorporation of $\mathrm{Cu}$ into $\mathrm{ZnO}-\mathrm{z}$. The Oads show a lower displacement at higher EB with respect to the support, but it also increases with the Cu content. In this system, copper is also selectively adsorbed on oxygen vacancies; but in a lesser degree than for the $\mathrm{Cux} / \mathrm{ZnO}-0$ system. If we compare the occupied Oads in percentage terms, after $\mathrm{Cu}$ deposition, for $\mathrm{Cu} 1.0 / \mathrm{ZnO}-0$ it is $51 \%$, while for $\mathrm{Cu} 1.0 / \mathrm{ZnO}-\mathrm{z}$ it is $30 \%$; and the other extreme, for $\mathrm{Cu} 0.2 / \mathrm{ZnO}$ $\mathrm{z}$ the $\mathrm{O}$ ads are not modified by the addition of $\mathrm{Cu}$, while for $\mathrm{Cu} 0.2 / \mathrm{ZnO}-030 \%$ is occupied. These results allow us to infer that in $\mathrm{Cux} / \mathrm{ZnO}-0$ part of the deposited $\mathrm{Cu}$ is incorporated into the $\mathrm{ZnO}$ lattice, while the rest of it is selectively adsorbed on the oxygen vacancies, leading to a nucleation process to obtain $\mathrm{CuO}$. As in $\mathrm{Cux} / \mathrm{ZnO}-\mathrm{z}$, a higher percentage of $\mathrm{Cu}$ is incorporated into the lattice of the milled support; the rest is located in the oxygen vacancies, forming $\mathrm{CuO}$. Therefore, different $\mathrm{Cu}$ contents with $\mathrm{Cu}^{2+}$ and $\mathrm{Cu}^{+}$valences can be expected in the two systems.

Table 2. XPS and TPR analysis of supports and catalysts.

\begin{tabular}{|c|c|c|c|c|c|c|c|c|c|c|}
\hline \multirow[t]{2}{*}{ Catalyst } & \multicolumn{2}{|c|}{ O 1s (eV) } & \multirow[t]{2}{*}{$\begin{array}{c}\mathrm{Zn} 2 \mathrm{p}_{3 / 2} \\
(\mathrm{eV})\end{array}$} & \multirow[t]{2}{*}{$\begin{array}{c}\mathrm{O}_{\mathrm{ads}} / \\
\left(\mathrm{O}_{\mathrm{ads}}+\mathrm{O}_{\text {lat }}\right)\end{array}$} & \multirow[t]{2}{*}{$\begin{array}{c}\mathrm{Cu} 2 \mathrm{p}_{3 / 2} \\
(\mathrm{eV})\end{array}$} & \multicolumn{2}{|c|}{\begin{tabular}{c}
\multicolumn{2}{c}{ Reduction } \\
Temperature $\left({ }^{\circ} \mathrm{C}\right)$
\end{tabular}} & \multicolumn{3}{|c|}{ 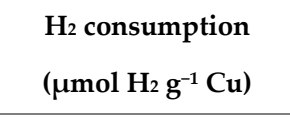 } \\
\hline & $O$ red & $\mathrm{O}$ ads & & & & Signal 1 & Signal 2 & Exp. & $\mathrm{CuO}$ & $\mathrm{Cu}_{2} \mathrm{O}$ \\
\hline $\mathrm{ZnO}-0$ & 530.15 & 531.67 & 1021.38 & 35.60 & - & - & - & - & - & - \\
\hline $\mathrm{Cu} 0.2 / \mathrm{ZnO}-0$ & 530.43 & 532.07 & 1021.77 & 24.65 & 932.43 & 218 & 267 & 26.6 & 31.4 & 17.5 \\
\hline $\mathrm{Cu} 0.5 / \mathrm{ZnO}-0$ & 530.40 & 532.30 & 1021.73 & 21.53 & 932.73 & 217 & 272 & 67.8 & 87.5 & 45.5 \\
\hline $\mathrm{Cu1} .0 / \mathrm{ZnO}-0$ & 530.38 & 532.34 & 1021.58 & 17.44 & 932.31 & 213 & 262 & 109.5 & 149.6 & 83.2 \\
\hline $\mathrm{ZnO}-\mathrm{z}$ & 530.07 & 531.65 & 1021.28 & 24.30 & - & - & - & - & - & - \\
\hline $\mathrm{Cu} 0.2 / \mathrm{ZnO}-\mathrm{z}$ & 530.19 & 531.85 & 1021.29 & 24.67 & 932.52 & 213 & 243 & 21.5 & 25.1 & 14.0 \\
\hline $\mathrm{Cu} 0.5 / \mathrm{ZnO}-\mathrm{z}$ & 530.22 & 531.89 & 1021.45 & 22.03 & 932.44 & 200 & 244 & 42.9 & 70.3 & 39.2 \\
\hline $\mathrm{Cu} 1.0 / \mathrm{ZnO}-\mathrm{z}$ & 530.38 & 532.19 & 1021.59 & 17.07 & 932.39 & 200 & 241 & 88.1 & 120.7 & 66.2 \\
\hline
\end{tabular}

RTP is a bulk technique that provides information on the reducibility of the systems, the possible $\mathrm{Cu}$ oxidation states, and $\mathrm{Cu}-\mathrm{ZnO}$ interaction. The reduction profiles of the catalysts in both systems are the same. They present two overlapped signals, which move to lower reduction temperatures with the $\mathrm{Cu}$ content increase; while the supports do not present reduction signals in the temperature range studied. For Cux/ZnO-z the copper reducibility is higher than in the other system. All the catalysts have lower $\mathrm{Cu}$ reduction temperatures than that corresponding to the bulk $\mathrm{CuO}$ reduction $\left(347^{\circ} \mathrm{C}\right)$, indicating a strong copper-support interaction. The two signals present in the reduction profiles have been associated with the reduction of different copper species by different authors. Gao et al. [2] associate the first signal to the reduction of highly dispersed $\mathrm{CuO}$ and the signal at high temperature to bulk $\mathrm{CuO}$. G. Fierro et al. [8] associate them with the reduction of $\mathrm{CuO}$ with different interactions with $\mathrm{ZnO}$, while $\mathrm{X}$. Yang et al. [3] associate the signal at low temperature to the reduction of $\mathrm{Cu}^{2+}$ to $\mathrm{Cu}^{+}$and the signal at high temperature to the reduction of $\mathrm{Cu}^{+}$to $\mathrm{Cu}^{\circ}$. With the aim to better understand our results, the $\mathrm{H}_{2}$ consumptions were calculated and compared with the theoretical values, corresponding to the $\mathrm{Cu}$ content deposited in each catalyst; for the reduction of $\mathrm{CuO}$ and $\mathrm{Cu}_{2} \mathrm{O}$ (Table 2). Cux/ZnO-0 presents consumptions close to the theoretical ones for the exclusive reduction of $\mathrm{CuO}$, but when the copper content increases, the experimental consumptions are lower than the theoretical ones, which could indicate the presence of a low amount of $\mathrm{Cu}_{2} \mathrm{O}$. The coexistence of copper with both valences is possible due to electronic mobility that occurs from the support to the metal, as inferred from XPS. The greater amount of $\mathrm{Cu}_{2} \mathrm{O}$ with the increase in the copper content could be associated with highly dispersed small metallic domains, where the bulk of the metallic particle corresponds to $\mathrm{CuO}$, and the metal-support contact area, which would increase with dispersion and domain size reduction, is where $\mathrm{Cu}_{2} \mathrm{O}$ would be formed. On the contrary, $\mathrm{Cux} / \mathrm{ZnO}-$ 
$\mathrm{z}$ presents experimental consumptions close to the theoretical consumptions for the exclusive reduction of $\mathrm{Cu}_{2} \mathrm{O}$. In this case, with the increase in the copper content, the theoretical consumptions are higher than the theoretical for the exclusive reduction of $\mathrm{Cu}_{2} \mathrm{O}$, which would indicate the presence of a small amount of $\mathrm{CuO}$. The possibility of having $\mathrm{Cu}_{2} \mathrm{O}$ and $\mathrm{CuO}$, but in an inverse relationship to that of the unmilled system, could be explained by the greater incorporation of $\mathrm{Cu}$ in the $\mathrm{ZnO}$ lattice. This facilitates its reduction, possibly due to the formation of very small metallic domains, dispersed and with a greater interaction with the support, at low bulk $\mathrm{CuO}$, but increasing when more copper is added.

\section{Conclusions}

High energy milling generates an increase in the specific surface area of the support, and introduces defects and micro-stresses in the crystalline lattice, making it more reactive than the original crystalline structure. The vial and mill balls material has a great influence on the milling time, generating different changes in the solid for the same accumulated kinetic energy. The defects introduced in the support by the high energy milling increase the metal-support interaction, and the reducibility of the metal; and $\mathrm{Cu}$ insertion could be potentially stabilizing the $\mathrm{ZnO}$ lattice, as inferred from the techniques discussed in this work. As a consequence, it is possible a decrease in the sizes of metallic domains and an increase in their dispersion, which will soon be determined by chemisorption of $\mathrm{N}_{2} \mathrm{O}$. For $\mathrm{Cux} / \mathrm{ZnO}-\mathrm{z}$, the $\mathrm{CuO} / \mathrm{Cu}_{2} \mathrm{O}-\mathrm{ZnO}-\mathrm{z}$ generated interface could lead to an improvement in the activity, selectivity and stability of this system in the glycerol hydrogenolysis reaction. We can conclude that high energy milling is an environmentally friendly technique, and very powerful. It allows modifying the metal-support interactions, which could be reflected in the improvement of the performance of catalytic systems in liquid phase reactions.

Author Contributions: Conceptualization, M.K.L.G., M.R.M. and L.E.C.; research, M.K.L.G.; visualization, M.K.L.G.; writing - original draft, M.K.L.G.; writing - review, M.K.L.G., L.E.C. and M.R.M.; writing - editing, M.K.L.G.; validation, L.E.C. and M.R.M.; supervision, L.E.C. and M.R.M.; resources, M.R.M.

Funding: The authors acknowledge the Universidad Nacional de San Luis (UNSL), Agencia Nacional de Promoción Científica y Tecnológica (ANPCyT) and Consejo Nacional de Investigaciones Científicas y Técnicas (CONICET) for their financial support.

Conflicts of Interest: The authors declare no conflict of interest.

\section{References}

1. Quiroga, M.M.B.; Barbero, B.P.; Cadus, L.E. Synthesis of a catalyst of Mn-Fe-O by mechano-chemical reaction. Applied Catalysis A: General, 2014, 474, 26-33.

2. Gao Q.; Xu B.; Tong Q.; Fan Y. Selective hydrogenolysis of raw glycerol to 1,2-propanediol over $\mathrm{Cu}-\mathrm{ZnO}$ catalysts in fixed-bed reactor. Japan Soc. Biosc., Biot. Agrochem. 2015, 80, 215-220.

3. Yang X.; Chen H.; Menga Q.; Zheng H.; Zhu Y.; Wang Y. Insights into influences of nanoparticle size and metal-support interactions of $\mathrm{Cu} / \mathrm{ZnO}$ catalysts on activity for furfural hydrogenation. Catal. Sci. Technol., 2017, 7, 5625-5634. doi: 10.1039/C7CY01284E.

4. Othman A.A.; Ali M.A.; Ibrahim E.M.M.; Osman M.A. Influence of $\mathrm{Cu}$ doping on structural, morphological, photoluminescence, and electrical properties of $\mathrm{ZnO}$ nanostructures synthesized by icebath assisted sonochemical method. J. All. Comp. 2016, 683, 399-411.

5. Iribarren, A.; Hernández-Rodríguez, E.; Maqueira, L. Structural, chemical and optical evaluation of Cudoped $\mathrm{ZnO}$ nanoparticles synthesized by an aqueous solution method. Materials Research Bulletin, 2014, 60, 376-381.

6. Huang, C.; Wena, J.; Suna, Y.; Zhanga, M.; Baoa, Y.; Zhanga, Y.; Chena, L. $\mathrm{CO}_{2}$ hydrogenation to methanol over $\mathrm{Cu} / \mathrm{ZnO}$ plate model catalyst: Effects of reducing gas induced $\mathrm{Cu}$ nanoparticle morphology. Chemical Engineering Journal, 2019, 374, 221-230.

7. Kaskow, I.; Decyk, P.; Sobczak, I. The effect of copper and silver on the properties of Au-ZnO catalyst and its activity in glycerol oxidation. Applied Surface Science, 2018, 444, 197-207.

8. G. Fierro G., Lo Jacono M., Inversi M., Porta P., Cioci F., Lavecchia R. Study of the reducibility of copper in CuO-ZnO catalysts by temperature-programmed reduction. App. Catal. A: G. 1996, 137, 327-348. 
Publisher's Note: MDPI stays neutral with regard to jurisdictional claims in published maps and institutional affiliations.

(C) 2020 by the authors. Submitted for possible open access publication under the terms and conditions of the Creative Commons Attribution (CC BY) license (http://creativecommons.org/licenses/by/4.0/). 